\title{
PENGARUH TINGKAT INFLASI, SUKU BUNGA BI, DAN NILAI TUKAR RUPIAH TERHADAP RETURN ON ASSET PERBANKAN
}

\author{
Anisyah Fitriany ${ }^{1)}$, Achmad Nawawi ${ }^{2)}$ \\ ${ }^{1)}$ Mahasiswa Program Studi Akuntansi, Universitas Singaperbangsa Karawang \\ ${ }^{2)}$ Staff Pengajar Fakultas Ekonomi, Universitas Singaperbangsa Karawang \\ Email: anisyahfitriany18@gmail.com
}

Diterima 18 Desember 2020 / Disetujui 25 Februari 2021

\begin{abstract}
This research aims to find out how inflation, BI interest rates, and rupiah exchange rates affect the return on assets of persero banks in Indonesia. The method used in this research is descriptive and verifikative research method. The data was obtained from the financial statements of persero banks, consisting of Bank Mandiri, Bank Tabungan Negara, Bank Negara Indonesia, and Bank Rakyat Indonesia which were published on the official website of the Financial Services Authority during the quarter of 2017 to the quarter of 2019. Sampling in this study is based on saturated sampling techniques, i.e. all members of the population are sampled. The data in this research is processed using SPSS software. Data processing and analysis techniques use multiple regression analysis. The results of this study showed that together (simultaneously) independent variables of Inflation Rate, BI Interest Rate, and Rupiah Exchange Rate had a significant effect on Bank Persero's ROA in Indonesia in 2017-2019. The test results partially showed that the Variable Inflation Rate negatively and significantly affects return on assets at the persero banks registered with the Financial Services Authority for the period 2017-2019, bi interest rate variables have no effect on Return On Assets on persero banks registered with the Financial Services Authority for the period 2017-2019, rupiah exchange rate variables have a positive and significant effect on Return On Assets on persero banks registered with the Financial Services Authority for the period 2017-2019. Based on the test results determining the amount of coefficient of determination of $18 \%$ while the remaining $82 \%$ is explained by other variables that are not included in the regression model equation.
\end{abstract}

Keywords: Inflation Rate, Bi Interest Rate, Rupiah Exchange Rate, Return On Assets

\begin{abstract}
ABSTRAK: Penelitian ini bertujuan untuk mengetahui bagaimana pengaruh inflasi, suku bunga BI, dan nilai tukar rupiah terhadap return on asset bank persero yang ada di Indonesia. Metode yang digunakan dalam penelitian ini adalah metode penelitian deskriptif dan verifikatif. Data diperoleh dari laporan keuangan bank persero, yang terdiri dari Bank Mandiri, Bank Tabungan Negara, Bank Negara Indonesia, dan Bank Rakyat Indonesia yang publikasi di website resmi Otoritas Jasa Keuangan selama triwulan tahun 2017 sampai dengan triwulan tahun 2019. Pengambilan sampel dalam penelitian ini didasarkan pada teknik sampling jenuh, yaitu semua anggota populasi dijadikan sampel. Data dalam penelitian ini diolah menggunakan software SPSS. Teknik pengolahan dan analisis data menggunakan analisis regresi berganda. Hasil dari penelitian ini menunjukkan hasil bahwa secara bersama-sama (simultan) variabel independen Tingkat Inflasi, Suku Bunga BI, dan Nilai Tukar Rupiah berpengaruh signifikan terhadap ROA Bank Persero di Indonesia tahun 2017-2019. Hasil pengujian secara parsial menunjukkan hasil bahwa variabel Tingkat Inflasi berpengaruh negatif dan signifikan terhadap Return On Asset pada bank persero yang terdaftar di Otoritas Jasa Keuangan periode 20172019, variabel Suku Bunga BI tidak memiliki pengaruh terhadap Return On Asset pada bank persero yang terdaftar di Otoritas Jasa Keuangan periode 2017-2019, variabel Nilai Tukar Rupiah berpengaruh positif dan signifikan terhadap Return On Asset pada bank persero yang terdaftar di Otoritas Jasa Keuangan periode 20172019. Berdasarkan hasil uji determinasi besarnya koefisien determinasi sebesar $18 \%$ sedangkan sisanya $82 \%$ dijelaskan oleh variabel lain yang tidak dimasukkan dalam persamaan model regresi.
\end{abstract}

Kata Kunci: Tingkat Inflasi, Suku Bunga BI, Nilai Tukar Rupiah, Return On Assets. 


\section{Pendahuluan}

Lembaga perbankan merupakan salah satu tulang punggung perekonomian suatu negara, karena memiliki fungsi sebagai perantara antara pemilik modal dan pihak yang memerlukan modal. Hampir seluruh segi aktivitas perekonomian memanfaatkan perbankan sebagai lembaga keuangan yang dapat menjamin berjalannya aktivitas usaha atau bisnis. Bank merupakan lembaga keuangan terpenting dan sangat memengaruhi perekonomian baik secara mikro maupum makro. Seperti yang diketahui, perbankan mempunyai pangsa pasar besar sekitar $80 \%$ dari keseluruhan sistem keuangan yang ada.

Penelitian ini mengambil kejadian pada tahun 2018, perang dagang antara Amerika Serikat dengan China kian memanas. Hal ini memengaruhi kondisi pelemahan rupiah. Pelemahan rupiah dimulai dengan persepsi investasi penanaman modal, ketika investor ingin menanamkan modal dalam suatu negara, tentu pasar harus melihat prospek ekonomi tersebut. Jika memiliki prospek yang baik, maka aliran dana akan masuk ke negara tersebut dan permintaan mata uang negara tersebut akan meningkat. dan berdampak pada perkembangan profitabilitas perbankan. Hal tersebut adalah yang terjadi di Indonesia pada tahun 2018 dengan nilai tukar rupiah. Perang dagang antar dua negara besar akan berpengaruh pada kinerja ekspor global yang melemah, sehingga pertumbuhan ekonomi global juga ikut berhenti. Pelemahan kinerja ekspor juga terjadi di Indonesia, sehingga Bank Indonesia perlu melakukan tindakan terhadap suku bunga acuan untuk dapat memacu kinerja ekspor Indonesia. Nilai tukar rupiah yang cenderung terdepresiasi juga merupakan dampak dari kebijakan Bank Sentral Amerika Serikat yang berencana menaikkan suku bunga acuan pada tahun 2018. Menanggapi hal tersebut, Bank Indonesia menaikkan suku bunga acuan menjadi 5,5\%. Pasalnya, kenaikan suku bunga akan menahan kredit, tapi jika kebijakan Bank Indonesia tidak diikuti, maka rupiah akan semakin terdepresiasi.

Kondisi yang demikian tentu memaksa industri perbankan lebih kreatif dan inovatif dalam mengembangkan dan memperoleh sumber dana baru. Oleh karena itu, bank di Indonesia mengalami persaingan antar bank untuk menarik dana dari masyarakat. Karena, bagi pihak bank, dana merupakan persoalan yang paling utama. Sementara dari berbagai jenis bank umum, bank persero memiliki peran penting dalam industri perbankan Indonesia, karena menurut data yang dihimpun Bank Indonesia, bank persero memiliki aset yang sangat besar. Perbankan sebagai lembaga yang berperan penting dalam perekonomian, maka diperlukan pengawasan kinerja yang baik dalam perbankan. Salah satu indikator yang tepat untuk menilai kinerja keuangan perbankan adalah dengan melihat tingkat profitabilitas bank tersebut. Karena tujuan utama perbankan adalah mencapai tingkat profit yang maksimal. Profitabilitas sebagai indikator kemampuan sebuah bank dalam mencari keuntungan dan mengasilkan laba secara efektif dan efisien. Dengan semakin banyaknya laba yang dihasilkan perbankan, hal itu mampu menunjukkan tingkat baik kinerja keuangan suatu bank. Return On Asset (ROA) digunakan untuk mengukur profitabilitas bank karena Bank Indonesia selaku bank pembina dan pengawas perbankan lebih mengutamakan nilai profitabilitas suatu bank yang diukur dengan nilai aset yang dananya sebagian besar merupakan dana simpanan dari masyarakat. ROA merupakan rasio yang terpenting di antara rasio profitabilitas yang ada.

Faktor penentu profitabilitas dapat dilihat dari faktor internal maupun faktor eksternal. Faktor eksternal merupakan faktor di luar kendali bank meliputi kebijakan moneter, fluktuasi nilai tukar (kurs) dan tingkat inflasi, volatilitas tingkat bunga, globalisasi, perkembangan teknologi, persaingan antar bank maupun lembaga keuangan non-bank, dan inovasi instrumen keuangan. Faktor eksternal tidak memiliki hubungan langsung dengan manajemen bank, tetapi secara tidak langsung memberikan efek bagi perekonomian dan hukum yang akan berdampak pada kinerja lembaga keuangan.

Faktor eksternal yang dijadikan variabel dalam penelitian ini adalah Inflasi, Suku Bunga BI, dan Nilai Tukar Rupiah. Inflasi adalah kenaikan yang menyeluruh dari 
jumlah uang yang harus dibayarkan (nilai unit peghitungan moneter) terhadap barang/komoditas dan jasa (Karim, 2013). Suku bunga Bank Indonesia adalah suku bunga kebijakan yang mencerminkan sikap atau stance kebijakan moneter yang ditetapkan oleh Bank Indonesia dan diumumkan kepada publik. Nilai Tukar Rupiah atau Kurs adalah perbandingan nilai tukar mata uang suatu negara dengan mata uang negara asing atau perbandingan nilai tukar valuta antar negara. Kurs Bank Indonesia (Kurs Standar = Kurs Pajak) adalah kurs yang ditetapkan oleh bank indonesia pada bursa valas di Jakarta.

Berdasarkan fenomena yang terjadi pada bank persero, karena bank persero merupakan bank yang terdiri dari empat bank dan menempati 10 besar bank dengan total aset terbesar maka bank persero menjadi penting untuk dilakukan penelitian. Berdasarkan uraian latar belakang masalah tersebut, maka penulis tertarik untuk mengetahui, menganalisis, dan menjelaskan pengaruh Inflasi, Suku Bunga BI, dan Nilai Tukar Rupiah terhadap kinerja perbankan yang diukur dengan ROA pada Bank Persero periode 2017 - 2019

\section{Pengembangan Hipotesis}

\section{Pengaruh Inflasi Terhadap ROA Perbankan}

Inflasi mempunyai arah hubungan yang positif dengan jumlah uang beredar. Semakin tinggi inflasi maka semakin banyak pula uang yang beredar di masyarakat. Begitu pula sebaliknya, saat terjadi deflasi maka uang yang beredar akan mengalami penurunan. Banyaknya jumlah uang yang beredar ini yang akan berpengaruh pada Profitabilitas Bank.

Dwijayanthy dan Naomi (2009) dan Hasibuan (2014) menyatakan bahwa Inflasi berpengaruh terhadap profitabilitas bank. Hal ini mengindikasikan naiknya tingkat inflasi akan berdampak pada beban operasional bank yang juga akan meningkat serta nilai suku bunga riil menurun yang mengakibatkan hasrat masyarakat untuk menabung di bank akan berkurang. Dengan naiknya tingkat inflasi maka suku bunga akan naik dan mengakibatkan masyarakat meminjam dana kepada bank. Selain itu perusahaan sektor riil juga enggan untuk menambah modal guna membiayai produksinya, yang pada akhirnya akan berdampak pada turunnya profitabilitas bank. Bila laju inflasi sangat tinggi (hyperinflation) akan menimbulkan ketidakpastian dalam berusaha sehingga akan mengganggu kegiatan operasional bank. Kenaikan inflasi akan berpengaruh positif terhadap ROA apabila diikuti dengan kenaikan suku bunga dan tingginya nilai tukar. Jadi diharapkan para calon nasabah bank bersedia menempatkan dananya di bank karena bunga yang akan mereka peroleh menjadi lebih tinggi, namun hal tersebut juga akan membuat bank memiliki biaya operasional yang lebih tinggi. Hal ini sejalan dengan penelitian yang dilakukan Hasibuan (2014) yang menyatakan hal serupa.

$\mathrm{H}_{1}$ : Terdapat pengaruh antara inflasi terhadap ROA

\section{Pengaruh Suku Bunga BI Terhadap ROA Perbankan}

Semakin tinggi tingkat suku bunga, maka akan semakin tinggi pula biaya yang harus ditanggung seseorang dalam memegang uang tunai. Apabila menyimpan semua pendapatannya di lembaga keuangan maka orang tersebut akan memperoleh keuntungan dari bunga tetapi tidak bisa melakukan transaksi untuk melakukan konsumsi, dapat ditarik kesimpulan bahwa jika suku bunga mengalami kenaikan maka minat masyarakat untuk memegang tunai akan semakin sedikit. Mereka akan lebih memilih menyimpan uang di bank. Karena mereka akan mendapatkan keuntungan dari simpanan di bank tersebut berupa bunga yang diberikan. Hal tersebut akan memengaruhi profitabilitas bank.

Penelitian yang dilakukan Fathoni (2017) dan menyatakan bahwa suku bunga tidak berpengaruh signifikan terhadap ROA disebabkan karena tingginya suku bunga, baik suku bunga pinjaman maupun suku bunga simpanan atau tabungan tetap menghasilkan spread margin dari selisih kedua bunga tersebut tetap, sehingga suku bunga tidak memengaruhi profitabilitas perbankan. 
$\mathrm{H}_{2}$ : Terdapat pengaruh antara suku bunga BI terhadap ROA.

\section{Pengaruh Nilai Tukar Rupiah Terhadap ROA Perbankan}

Kurs akan memengaruhi keputusan masyarakat dalam hal menabung. Saat kurs rupiah mengalami apresiasi, masyarakat akan memilih menyimpan uang dalam bentuk rupiah. Hal ini disebabkan karena masyarakat akan mendapat keuntungan dari penguatan nilai tukar rupiah. Sebaliknya, apabila rupiah mengalami depresiasi, maka masyarakat akan memilih menyimpan uang dalam bentuk mata uang asing untuk menghindari efek inflasi.

Nilai tukar mata uang asing menjadi salah satu faktor profitabilitas bank karena dalam kegiatan operasionalnya, bank memberikan jasa jual beli valuta asing. Dalam situasi normal, memperdagangkan valuta asing sangat menguntungkan karena transaksi menghasilkan keuntungan berupa selisih kurs. Dalam kegiatan transaksi tersebut, nilai tukar akan mata uang asing menjadi perhatian bank karena mampu memengaruhi tingkat profitabilitas bank. Penelitian yang dilakukan Swandayani dan Kusumaningtias (2012) dan Purtanti (2015), menunjukkan nilai tukar mata uang asing berpengaruh positif terhadap ROA. Setiap kenaikan nilai tukar mata uang asing akan mengakibatkan kenaikan ROA, dan sebaliknya setiap penurunan nilai tukar mata uang asing akan menurunkan ROA.

$\mathrm{H}_{3}$ : Terdapat pengaruh antara nilai tukar rupiah terhadap ROA.

\section{Metode Penelitian}

Metode penelitian yang digunakan adalah metode deskriptif verifikatif. Metode deskriptif menurut Sugiyono (2013) adalah Suatu rumusan masalah yang berkenaan dengan pertanyaan terhadap keberadaan variable mandiri, baik hanya pada satu variable atau lebih. Sugiyono (2013) juga mendeskripsikan metode verifikatif adalah metode penelitian melalui pembuktian untuk menguji hipotesis hasil penelitian dekriptif dengan perhitungan statistika sehingga didapat hasil pembuktian yang menunjukan hipotesis ditolak atau diterima.

Berdasarkan metode yang telah diuraikan, penulis mengumpulkan data historis dan mengamati secara seksama mengenai aspek-aspek tertentu yang berkaitan dengan masalah yang diteliti sehingga akan diperoleh data-data yang menunjang penyusunan laporan penelitian. Adapun pendekatan yang digunakan dalam penelitian ini adalah pendekatan kuantitatif. Menurut Sugiyono (2013) metode penelitian kuantitatif adalah metode penelitian yang berlandaskan pada filsafat positivisme, digunakan untuk meneliti pada populasi atau sampel tertentu, pengumpulan data menggunakan instrumen penelitian, analisis data bersifat kuantitatif atau statistik, dengan tujuan menguji hipotesis yang telah ditetapkan.

\section{Variabel Penelitian}

a. Variabel Dependen

Variable dependen atau terikat sering juga disebut variabel kriteria respon output (hasil). Variabel dependen merupakan variabel yang dipengaruhi atau yang menjadi akibat karena adanya variabel independen (bebas).Variabel dependen pada penelitian ini adalah Return On Assets (ROA). ROA digunakan karena Bank Indonesia sebagai pembina dan pengawas perbankan lebih mengutamakan nilai profitabilitas suatu bank yang diukur dengan aset yang dananya sebagian besar dari simpanan masyarakat.

Rasio ini dirumuskan sebagai berikut (Surat Edaran BI No 13/24/DPNP tanggal 25 Oktober 2011)

Return On Assets $=\frac{\text { Laba Sebelum Pajak }}{\text { Rata-Rata Total Assets }}$

b. Variabel Independen

Variable Independen sering disebut juga variabel prediktor, stimulus, input, antencendent atau variabel yang memengaruhi. Variabel independen merupakan variabel yang menjadi sebab timbulnya atau berubahnya variabel dependen. Variabel Independen dalam penelitian ini terdiri dari: 
1. Inflasi

Inflasi menurut Bank Indonesia adalah meningkatnya harga-harga secara umum dan terus-menerus. Kenaikan harga dari satu atau dua barang saja tidak dapat disebut inflasi, kecuali bila kenaikan tersebut meluas (atau mengakibatkan kenaikan harga) pada barang lainnya.

2. Suku Bunga BI

Suku bunga BI merupakan suku bunga dengan tenor satu bulan yang diumumkan oleh Bank Indonesia secara periodik memiliki fungsi sebagai sinyal kebijakan moneter. Secara sederhana, suku bunga BI merupakan indikasi tingkat suku bunga jangka pendek yang diinginkan Bank Indonesia dalam upaya mencapai target inflasi.

3. Nilai Tukar Rupiah

Nilai tukar adalah nilai harga dari sebuah mata uang yang dibandingkan dengan nilai mata uang eropa dan amerika dan lainya guna memenuhi kebutuhan perdagangan internasional serta melakukan pembayaran luar negeri.

Variabel tingkat inflasi maupun tingkat suku bunga merupakan dua variabel makroekonomi yang berdampak besar pada perekonomian secara umum. Jika suatu perekonomian mengalami tingkat inflasi yang tinggi, maka nilai riil uang menurun yang menyiratkan daya beli yang lebih sedikit, profitabilitas yang lebih sedikit, dan penurunan pengembalian riil atas investasi.

\section{Populasi, Sampel, dan Sumber Data}

Populasi menurut Sujarweni (2016), populasi adalah keseluruhan jumlah yang terdiri atas obyek atau subyek yang mempunyai karakteristik dan kualitas tertentu yang ditetapkan oleh peneliti untuk diteliti dan kemudian ditarik kesimpulannya. Populasi yang digunakan dalam penelitian ini adalah Bank Persero yang terdaftar di Otoritas Jasa Keuangan, yaitu Bank Mandiri, Bank Tabungan Negara (BTN), Bank Negara
Indonesia (BNI), dan Bank Rakyat Indonesia (BRI).

Sampel menurut Sugiyono (2017:81), sampel adalah bagian dari jumlah dan karakteristik dan dimiliki oleh populasi tersebut. Pengukuran sampel merupakan suatu langkah untuk menentukan besarnya sampel yang diambil dalam melaksanakan suatu penelitian. sampel harus dapat menggambarkan keadaan populasi yang sebenarnya atau mewakili (representatif). Teknik pengambilan sampel yang digunakan dalam penelitian ini adalah nonprobability sampling, menurut Sugiyono (2017:84) nonprobability sampling yaitu teknik pengambilan sampel yang tidak memberi peluang/kesempatan sama bagi setiap unsur atau anggota populasi untuk dipilih menjadi sampel. Teknik yang diambil adalah sampling jenuh, menurut Sugiyono (2017) sampling jenuh adalah teknik penentuan sampel bila semua anggota populasi digunakan sebagai sampel. Maka dari itu, sampel dalam penelitian ini adalah seluruh anggota populasi yang terdiri dari empat bank persero, yaitu Bank Mandiri, Bank Tabungan Negara (BTN), Bank Negara Indonesia (BNI), dan Bank Rakyat Indonesia (BRI).

Jenis data yang digunakan dalam penelitian ini yaitu jenis data kuantitatif yang merupakan data time series periode 20172019. Adapun sumber data penelitian ini menggunakan data sekunder yaitu berupa data laporan keuangan triwulan yang dipublikasikan dalam laman resmi Otoritas Jasa Keuangan. Data yang digunakan berjumlah 48 data yang didapatkan dari Laporan Keuangan BNI, BRI, BTN, dan Bank Mandiri per triwulan selama 3 tahun. Data sekunder adalah data yang diperoleh peneliti dari sumber yang telah ada, yang telah dipublikasikan oleh sumber terpercaya.

\section{Metode Analisis Data}

Analisis regresi berganda digunakan untuk menjawab rumusan masalah dalam penelitian ini. Metode regresi berganda digunakan karena memiliki lebih dari satu variabel independen. Analisis ini untuk mengetahui arah hubungan antara variabel 
independen dengan variabel dependen apakah masing-masing variabel independen berhubungan positif atau negatif. Rumus yang digunakan sebagai berikut:

$\mathrm{Y}=\alpha+\beta 1 \mathrm{X} 1+\beta 2 \mathrm{X} 2+\beta 3 \mathrm{X} 3+\mathrm{e}$

Keterangan:

$\mathrm{Y} \quad=$ Variabel dependen (ROA)

$\mathrm{X} 1=$ Variabel independen (Inflasi)

$\mathrm{X} 2=$ Variabel independen (Suku Bunga $\mathrm{BI})$

X3 = Variabel independen (Nilai tukar rupiah)

$\alpha \quad=$ Konstanta

$\beta=$ Koefisien regresi

e $\quad=$ Error

Hasil Dan Pembahasan
Berdasarkan tabel 1 dapat dijelaskan mengenai statistik deskriptif data yang digunakan dalam penelitian ini, yakni sebagai berikut. Hasil statistik deskriptif pada tabel 1 menunjukkan bahwa nilai minimum ROA sebesar $0,13 \%$ dan nilai maksimum sebesar $3,69 \%$. Hal ini menunjukkan bahwa besarnya ROA pada sampel penelitian ini berkisar antara $0,13 \%$ sampai $3,69 \%$ dengan rata-rata (mean) 2,5596 pada standar deviasi sebesar 0,89543 . Nilai ROA tertinggi pada Bank Rakyat Indonesia pada Triwulan IV Tahun 2017 yaitu 3,69\%, sedangkan nilai ROA terendah pada Bank Tabungan Negara pada Triwulan IV Tahun 2019 sebesar 0,13\%.

Tabel 1 : Hasil Pengolahan Statistik Deskriptif

Descriptive Statistics

\begin{tabular}{lrrrrr}
\hline & N & Minimum & Maximum & \multicolumn{1}{c}{ Mean } & \multicolumn{1}{c}{ Std. Deviation } \\
\hline Inflasi & 48 & 2,62 & 4,29 & 3,3417 & 0,41771 \\
Suku Bunga BI & 48 & 4,25 & 6,00 & 5,0983 & 0,65144 \\
Nilai Tukar & 48 & 13310 & 14812 & $1.3922 \mathrm{E} 4$ & 488.98540 \\
ROA & 48 & 0,13 & 3,69 & 2,5596 & 0,89543 \\
Valid N & 48 & & & & \\
\hline
\end{tabular}

Sumber : hasil olah data

Hasil statistik deskriptif pada tabel 1 menunjukan bahwa nilai minimum inflasi sebesar 2,62 dan nilai maksimum sebesar 4,29. Hal ini menunjukkan bahwa besarnya Inflasi pada sampel penelitian ini berkisar antara 2,62 sampai 4,29 dengan rata-rata (mean) 3,3417 pada standar deviasi sebesar 0,41771. Nilai Inflasi tertinggi pada penelitian ini terjadi pada Triwulan II Tahun 2017 yaitu 4,29, sedangkan nilai Inflasi terendah pada penelitian ini terjadi pada Triwulan I Tahun 2019 sebesar 2,62.

Hasil statistik deskriptif pada tabel 1 menunjukan bahwa nilai minimum suku bunga BI sebesar 4,25 dan nilai maksimum sebesar 6,00. Hal ini menunjukkan bahwa besarnya Suku Bunga BI pada sampel penelitian ini berkisar antara 4,25 sampai
6,00 dengan rata-rata (mean) 5,0983 pada standar deviasi sebesar 0,65144. Nilai Suku Bunga BI tertinggi pada penelitian ini terjadi pada Triwulan IV Tahun 2018, Triwulan I Tahun 2019, serta Triwulan II tahun 2019 yaitu sebesar 6,00, sedangkan nilai Suku Bunga BI terendah pada penelitian ini terjadi pada Triwulan IV Tahun 2017 dan Triwulan I Tahun 2018 sebesar 4,25.

Hasil statistik deskriptif pada tabel 1 menunjukan bahwa nilai minimum dari nilai tukar rupiah sebesar $\mathrm{Rp} 13.310$ dan nilai maksimum sebesar $\mathrm{Rp}$ 14.812. Hal ini menunjukkan bahwa besarnya Nilai tukar rupiah pada sampel penelitian ini berkisar antara Rp 13.310 sampai Rp 14.182 dengan rata-rata (mean) 1.3922E4 pada standar deviasi sebesar 488.98540. Nilai dari nilai 
tukar rupiah tertinggi pada penelitian ini terjadi pada Triwulan IV Tahun 2018 yaitu sebesar Rp 14.812, sedangkan nilai tukar rupiah terendah pada penelitian ini terjadi pada Triwulan II Tahun 2017 sebesar Rp 13.310 .

\section{Uji Asumsi Klasik}

Uji asumsi klasik yang telah dilakukan menunjukan bahwa ;

1. Uji Normalitas

Data berdistribusi normal karena nilai Asymp. Sig. (2-tailed) 0,578 lebih dari 0,05

2. Uji Multikolinearitas

Tidak ada variabel independen yang memiliki tolerance kurang dari 0,10. Hasil perhitungan nilai Variance Inflation Factor (VIF) juga menunjukkan hal yang sama yaitu tidak ada variabel independen yang memiliki nilai VIF lebih dari 10. yaitu 1,916 untuk variabel Inflasi, 2,881 untuk variabel Suku Bunga BI, dan 3,835 untuk variabel Nilai Tukar Rupiah.

3. Uji Heteroskedastisitas

Titik-titik menyebar secara acak, serta tersebar baik di atas maupun di bawah angka 0 pada sumbu Y. hal ini berarti tidak ada problem heteroskedastisitas pada penelitian ini.

4. Uji Autokorelasi

Durbin Watson penelitian ini adalah 2,496. Pada penelitian ini di dapat nilai du sebesar 1,7206 dimana du $<$ d $<4$-du hasil yang diperoleh $1,7206<2,196<$ 2,2794 maka dapat disimpulkan bahwa penelitian ini tidak terdapat masalah autokorelasi.

\section{Uji Hipotesis}

Analisis Regresi Berganda

Tabel 2 : Hasil Uji Regresi Linear Berganda

\begin{tabular}{|c|c|c|c|c|}
\hline & & \multicolumn{2}{|c|}{ Unstandardized Coefficients } & $\begin{array}{l}\text { Standardized } \\
\text { Coefficients }\end{array}$ \\
\hline \multicolumn{2}{|c|}{ Model } & $\mathrm{B}$ & Std. Error & Beta \\
\hline \multirow[t]{4}{*}{1} & (Constant) & -.056 & .053 & \\
\hline & Inflasi & -.205 & .095 & -.290 \\
\hline & Suku Bunga BI & -.036 & .126 & -.048 \\
\hline & Nilai Kurs & .020 & .027 & .387 \\
\hline
\end{tabular}

Berdasarkan tabel 2 dapat dikembangkan dengan menggunakan model persamaan regresi linear berganda sebagai berikut: $\mathrm{Y}=\alpha+\beta 1 \mathrm{X} 1+\beta 2 \mathrm{X} 2+\beta 3 \mathrm{X} 3+\mathrm{e}$, apabila nilai pada tabel 2 disubsitusikan maka akan diperoleh nilai sebagai berikut:

$\mathrm{Y}=-0,056-0,205 \mathrm{X} 1-0,036 \mathrm{X} 2+0,000 \mathrm{X} 3$

$+\mathrm{e}$.

a) Konstanta sebesar -0,056 artinya jika Inflasi, Suku Bunga BI, dan Nilai Tukar Rupiah tidak ada maka ROA turun sebesar 0,056

b) Koefisien regresi X1 sebesar -0,205 artinya setiap kenaikan satu satuan Inflasi akan menurunkan ROA sebesar 0,205. Begitupun sebaliknya, setiap penurunan satu satuan Inflasi akan menaikkan ROA sebesar 0,205 dengan anggapan bahwa X2 dan X3 tetap.

c) Koefisien regresi $\mathrm{X} 2$ sebesar $-0,036$ artinya setiap kenaikan satu satuan Suku Bunga BI akan menurunkan ROA sebesar 0,036. Begitupun sebaliknya, setiap penurunan satu satuan Suku Bunga BI akan menaikkan ROA sebesar 0,036 dengan anggapan bahwa X1 dan X3 tetap. 
d) Koefisien regresi X3 sebesar 0,000 artinya setiap kenaikan satu satuan Nilai Tukar Rupiah akan meningkatkan ROA sebesar 0,020. Begitupun sebaliknya, setiap penurunan satu satuan Nilai Tukar Rupiah akan menurunkan ROA sebesar 0,020 dengan anggapan bahwa X1 dan X2 tetap.
Uji t digunakan untuk mengetahui pengaruh secara parsial variabel independen terhadap variabel dependen. Pengujian dilakukan dengan membandingkan nilai $t_{\text {hitung }}$ dengan $\mathrm{t}_{\text {tabel }}$ dengan menggunakan signifikansi 0,05. Berikut adalah kriterianya:

$\mathrm{H}_{0}$ tidak ditolak, jika nilai $\mathrm{t}_{\text {hitung }}<\mathrm{t}_{\text {tabel }}$ $\mathrm{H}_{0}$ ditolak, jika nilai $\mathrm{t}_{\text {hitung }}>\mathrm{t}_{\text {tabel }}$

\section{Uji T (Parsial)}

Tabel 3 : Hasil Uji T

\begin{tabular}{|c|c|c|c|c|c|c|}
\hline \multirow{2}{*}{\multicolumn{2}{|c|}{ Model }} & \multicolumn{2}{|c|}{$\begin{array}{l}\text { Unstandardized } \\
\text { Coefficients }\end{array}$} & \multirow{2}{*}{$\begin{array}{c}\text { Standardized } \\
\text { Coefficients } \\
\text { Beta }\end{array}$} & \multirow[t]{2}{*}{$\mathrm{t}$} & \multirow[t]{2}{*}{ Sig. } \\
\hline & & B & Std. Error & & & \\
\hline 1 & (Constant) & -.056 & .053 & & -1.050 & .300 \\
\hline & Inflasi & -.205 & .095 & -.290 & & \\
\hline & Suku Bunga BI & -.036 & .126 & -.048 & -2.151 & .031 \\
\hline & Nilai Kurs & .000 & .000 & .387 & -.288 & .775 \\
\hline & & & & & 2.318 & .025 \\
\hline
\end{tabular}

Sumber : Hasil olah data

a) Pengujian Hipotesis Inflasi

Berdasarkan hasil pengolahan pada tabel 3 menunjukkan bahwa t hitung sebesar -2,151 dan $t$ tabel sebesar 2,015 , sehingga $\mathrm{t}$ hitung $>\mathrm{t}$ tabel sehingga dapat disimpulkan bahwa H0 ditolak dan H1 diterima yang menyatakan Inflasi yang digunakan pada penelitian ini berpengaruh terhadap ROA Bank Persero periode 2017-2019.

b) Pengujian Hipotesis Suku Bunga BI Berdasarkan hasil pengolahan pada tabel 3 menunjukkan bahwa t hitung sebesar $-0,288$ dan $t$ tabel sebesar 2,015, sehingga $\mathrm{t}$ hitung $<\mathrm{t}$ tabel sehingga dapat disimpulkan bahwa $\mathrm{H} 0$ diterima dan $\mathrm{H} 2$ ditolak. Berarti hipotesis 2 yang menyatakan Suku Bunga BI berpengaruh terhadap ROA Bank Persero adalah tidak berpengaruh terhadap ROA Bank Persero periode 2017-2019.

c) Pengujian Hipotesis Nilai Tukar Rupiah
Berdasarkan hasil pengolahan pada tabel 3 menunjukkan bahwa nilai $\mathrm{t}$ hitung sebesar 2,318 dan $t$ tabel sebesar 2,015, sehingga $t$ hitung $>t$ tabel sehingga dapat disimpulkan bahwa H0 ditolak dan $\mathrm{H} 3$ diterima yang menyatakan Nilai Tukar Rupiah yang digunakan pada penelitian ini berpengaruh terhadap ROA Bank Persero periode 2017-2019.

\section{Uji F (Simultan)}

Uji F digunakan untuk mengetahui apakah variabel independen secara bersamasama (simultan) berpengaruh terhadap variabel dependen. Pedoman yang digunakan untuk menerima atau menolak hipotesis yaitu: $\mathrm{H}_{0}$ ditolak, jika $\mathrm{F}_{\text {hitung }}>\mathrm{F}_{\text {tabel }}$

$\mathrm{H}_{0}$ tidak ditolak, jika $\mathrm{F}_{\text {hitung }}<\mathrm{F}_{\text {tabel }}$

Berdasarkan uji $\mathrm{F}$ didapat nilai Fhitung sebesar 4,367. Karena Fhitung > Ftabel $(4,367>2,812)$ dapat disimpulkan bahwa H0 ditolak dan H4 tidak ditolak yang menyatakan Inflasi, Suku Bunga BI, dan Nilai Tukar Rupiah secara simultan 
berpengaruh terhadap ROA Bank Persero periode 2017-2019.

\section{Koefisien Determinasi (Adjusted $R^{2}$ )}

Uji koefisien determinasi digunakan untuk mengukur seberapa jauh kemampuan model regresi dalam menerangkan variabel dependen. Nilai koefisien determinasi model regresi dapat dilihat dalam tabel sebagai berikut

\begin{tabular}{|c|c|c|c|c|c|c|}
\hline \multirow{3}{*}{\multicolumn{2}{|c|}{ Model }} & \multicolumn{4}{|c|}{ Tabel 4 Hasil Uji F } & \multirow{3}{*}{ Sig. } \\
\hline & & \multicolumn{4}{|l|}{ Sum of } & \\
\hline & & Square & Df & Mean Square & $\mathrm{F}$ & \\
\hline & Regression & .978 & 3 & .326 & 4.367 & .009 \\
\hline & Residual & 3.211 & 43 & .075 & & \\
\hline & Total & 4.189 & 46 & & & \\
\hline
\end{tabular}

Sumber : Hasil olah data

Tabel 5

Hasil Uji Koefisien Determinasi

\begin{tabular}{lrrrr} 
Model & R & R Square & $\begin{array}{c}\text { Adjusted R } \\
\text { Square }\end{array}$ & $\begin{array}{c}\text { Std. Error of the } \\
\text { Estimate }\end{array}$ \\
\hline 1 & $.483^{\text {a }}$ & .234 & .180 & .27325 \\
Sumber : Hasil olah data & & &
\end{tabular}

Berdasarkan tabel 5 terlihat Adjusted $\mathrm{R}$ Square sebesar 0,180 atau $18 \%$. Hal ini berarti variabel independen yang terdiri dari Inflasi, Suku Bunga BI, dan Nilai Tukar Rupiah memberikan informasi yang dibutuhkan untuk memprediksi variabel dependen sebesar $18 \%$. Sedangkan, sisanya $(100 \%-18 \%=82 \%)$ dipengaruhi oleh variabel lain di luar persamaan regresi ini atau variabel lain yang tidak di teliti.

\section{Simpulan}

Inflasi dalam penelitian ini memiliki hasil pengaruh dengan arah hubungan negative terhadap Return On Asset (ROA) Bank Persero periode 2017 - 2019. Hasil ini menunjukkan bahwa semakin tinggi inflasi maka ROA Bank Persero akan semakin turun, hubungan yang demikian terjadi karena inflasi yang meningkat akan menyebabkan nilai riil tabungan menurun yang disebabkan oleh masyarakat yang lebih memilih menggunakan hartanya untuk mencukupi biaya hidup yang meningkat akibat inflasi ketimbang menyimpan hartanya di bank sehingga akan memengaruhi profitabilitas perbankan.

Suku Bunga BI dalam penelitian ini tidak memiliki pengaruh terhadap Return On Asset (ROA) Bank Persero periode 2017 2019. Hal ini disebabkan karena fluktuasi Suku Bunga BI pada penelitian ini cenderung kecil, karena itu pada penelitian ini Suku Bunga BI tidak berpengaruh terhadap ROA. Pada stage ini Bank Indonesia selaku bank central harus mampu menahan suku bunga BI untuk menjaga stabilitas eksternal perekonomian Indonesia.

Nilai tukar rupiah dalam penelitian ini memiliki hasil pengaruh dengan arah hubungan negative terhadap Return On Asset (ROA) Bank Persero periode 2017 - 2019. Hasil ini menunjukkan bahwa terdapat pengaruh nilai tukar mata uang terhadap ROA mengidentifikasi apabila nilai tukar 
mengalami apresiasi maupun depresiasi, maka akan berdampak pada profitabilitas perbankan. Menguatnya nilai rupiah terhadap dollar AS akan menguatkan profitabilitas perbankan karena menurunkan harga barang impor yang berpotensi meningkatkan perekonomian pada sector riil dan mendorong masyarakat untuk berinvestasi pada sektor tersebut yang berpengaruh pada tingkat profitabilitas perbankan.

Nasabah hendaknya memerhatikan pergerakan Inflasi dan Nilai Tukar Rupiah, karena variabel ini telah terbukti berpengaruh signifikan terhadap Return On Assets bank persero, dengan mengetahui apa saja yang terbukti memengaruhi Return On Assets berarti mengetahui tingkat kesehatan suatu bank, sehingga dapat menentukan strategi investasi.

Penelitian ini masih memiliki keterbatasan yaitu dari segi makro ekonomi yang digunakan sebagai variabel penelitian hanya Inflasi, Suku Bunga BI, dan Nilai Tukar Rupiah, diharapkan dalam penelitian selanjutnya untuk membawa pengaruh faktor lain yang dapat memengaruhi Return On Assets bank persero.

Penelitian selanjutnya diharapkan dapat dilakukan pada jenis atau kategori perbankan lainnya yang terdaftar di Otoritas Jasa Keuangan untuk menambah validitas hasil penelitian.

\section{Daftar Pustaka}

Astuty, P., \& Rahman, M. N. (2015). Analisis Pengaruh Dana Pihak Ketiga, BI Rate, dan Kurs Rupiah Terhadap Profitabilitas (ROA) pada Bank Persero Di Indonesia Periode 20082014, Volume 17 (Nomor 3), 324-337.

Azwar, S. (2007). Metode Penelitian. Yogyakarta: Pustaka Pelajar.

Budisantoso, T., \& Nuritomo. (2011). Bank dan Lembaga Keuangan Lainnya. Jakarta: Salemba Empat.

Dendawijaya, L. (2003). Manajemen Perbankan. Jakarta: Ghalia Indonesia.

Dwijayanthy, F., \& Naomi, P. (2009). Analisis Pengaruh Inflasi, BI Rate, dan
Nilai Tukar Mata Uang terhadap Profitabilitas Bank Periode 2003-2007, Volume 3 (Nomor 2), 87-98.

Eldomiaty, T., \& Saeed, Y. (2020). The associations between stockprices, inflation rates, interestrates are still persistent Empirical evidence from stock duration model, Volume 25 (Nomor 49) , 149-161

Fathoni, A. B. (2017). Pengaruh Inflasi, Suku Bunga, dan BOPO terhadap ROA Perbankan (Studi Pada Bank Umum Persero Periode 2013-2015).

Garbowski, M., Kozitska, N., Poliakova, Y., Karnilova, N., \& Syntsia, L. (2019). Organization Of Bank Accounting In The Conditions of The Financial Crisis, Volume 23, (Special Issue 2) .

Ghozali, I. (2006). Aplikasi Analisis Multivariate dengan Program SPSS. Semarang: Badan Penerbit Universitas Diponegoro.

Hasibuan, B. (2014). Pengaruh Tingkat Inflasi, Suku Bunga, dan Nilai Tukar Terhadap Kinerja Keuangan Perusahaan Perbankan Yang Listed di Bursa Efek Indonesia Periode Tahun 2008-2012, Volume 8 (Nomor 2) .

Hery. (2009). Akuntansi Keuangan Menengah 1. Jakarta: Bumi Aksara.

Karyani, S. S., \& Darmawan, A. (2020). Pengaruh Risiko Suku Bunga BI, Risiko Inflasi, dan Risiko Nilai Mata Uang Terhadap Profitabilitas, Volume 78 (Nomor 1), 173-180.

Kasmir. (2007). Manajemen Perbankan. Jakarta: PT. Raja Grafindo.

Majumder, T. H. (2017). Bank risk and performance in anemerging market setting: thecase of Bangladesh, Volume 23 (Nomor 46), 199-229

Ngerebo, T. (2012). The Impact of Foreign Exchange Fluctuation on the intermediation of Banks in Nigeria (1970-2004), (Volume 6 No 11)

Nugroho, G. A. (2020). Pengaruh Kurs Rupiah, Inflasi dan Suku Bunga terhadap Return Saham Perusahaan Sektor Jasa sub konstruksi dan bangunan pada Bursa Efek Indonesia, Volume 14 (Nomor 1), 38-43

Pan, Q., \& Pan, M. (2014). The Impact of Macro Factors on the Profitability of China's Commercial Banks in the 
Decade after WTO Accession, Volume 2, 64-69.

Prastowo, P. R., Mardani, R. M., \& Wahono, B. (2018). Analisis Pengaruh Inflasi, Suku Bunga, dan Nilai Tukar Terhadap Profitabilitas Perbankan, Volume 7 (Nomor 16) .

Sodikin, S. S., \& Riyono, A. B. (2008). Akuntansi Pengantar 1. Yogyakarta: STIM.
Sugiyono. (2017). Metode Penelitian Kuantitatif, Kualitatif, dan $R \& D$. Bandung: Alfabeta.

Sujarweni, V. W. (2016). Penelitian Akuntansi dengan SPSS. Yogyakarta: Pustaka Baru Press.

Sunarya, I. W. (2018). The Impact of Internal Performance and Macroeconomic Conditions on Profitability in Indonesian Banking From 2015-2017, Volume 6 (Nomor 2) , 122. 